\title{
ANALISIS A'WOT SEBAGAI PERENCANAAN PENGEMBANGAN DESA WISATA TIWINGAN LAMA KABUPATEN BANJAR
}

\author{
Sari Hepy Maharani, Tarman Effendi
}

Politeknik Negeri Banjarmasin, Kalimantan Selatan, Indonesia

Email: sarihepymaharani@poliban.ac.id, tarmaneffendi@poliban.ac.id

\begin{tabular}{l}
\hline INFO ARTIKEL \\
\hline Diterima \\
10 November 2021 \\
Direvisi \\
2 Desember 2021 \\
Disetujui \\
2 Januari 2022 \\
\hline
\end{tabular}

Kata Kunci: AHP; SWOT; Desa Wisata

\section{ABSTRAK}

Penelitian ini bertujuan untuk (1) mengetahui faktor internal objek wisata yang dapat mempengaruhi jumlah pengunjung Desa Wisata Tiwingan Lama, (2) mengetahui faktor eksternal daya tarik wisata yang dapat mempengaruhi jumlah pengunjung Desa Wisata Tiwingan Lama, dan (3) menentukan strategi pengembangan terbaik yang akan digunakan dalam rangka peningkatan jumlah pengunjung Desa Wisata Tiwingan Lama. Metode penelitian kualitatif digunakan dalam penelitian ini. Tinjauan pustaka, observasi, wawancara, kuesioner dan dokumentasi digunakan untuk memperoleh data untuk penelitian ini. Strategi analisis data yang digunakan dalam penelitian ini adalah analisis SWOT kualitatif dan AHP (Analytical Hierarchy Process). Temuan penelitian ini menunjukkan bahwa (1) Desa Wisata Tiwingan Lama merupakan desa wisata dengan berbagai potensi wisata, dan kondisi alam dengan panorama yang indah, lokasi yang strategis, dan akses yang memadai dari kota merupakan faktor internal yang berkontribusi terhadap kekuatan desa wisata Tiwingan Lama. (2) Faktor eksternal yang menjadi peluang pengembangan desa wisata Tiwingan Lama adalah perubahan tren pariwisata di masa pandemi dengan menjadikan desa wisata sebagai potensi wisata lokal desa wisata, sedangkan kelemahan desa adalah rendahnya kualitas SDM desa. dalam hal pariwisata. yang sebagian besar masih belum tergali, sedangkan kendala dalam pengembangan desa wisata Tiwingan Lama adalah potensi banjir dan (tanah) longsor serta kurangnya dukungan dari pemerintah setempat, dan (3) berdasarkan hasil analisis A'WOT terhadap kondisi Desa Tiwingan Lama, strategi yang digunakan paling tepat untuk digunakan dalam mengembangkan wisata di desa wisata Tiwingan Lama adalah strategi SO yaitu dengan mengembangkan potensi produk wisata yang ada di Desa Tiwingan Lama.

\section{ABSTRACT}

The study, titled " A'WOT Analysis as Planning for Development of the Tiwingan Lama Tourism Village, Banjar Regency " aims to (1) determine the internal factors of tourism objects that can affect the number of visitors to the Tiwingan Lama Tourism Village, (2) determine the external factors of tourist attractions that can affect the number of visitors to the Tiwingan Lama Tourism Village, and (3) determine the best development strategy to be used in order to increase the number of visitors to the Tiwingan Lama Tourism Village. The qualitative research method was used in this study. Literature review, observation, interviews, questionnaire and documentation were all employed to acquire data for this study. The data analysis strategy employed in this study was a 


qualitative SWOT analysis and AHP (Analytical Hierarchy Process). The
findings of this study show that (1) the Tiwingan Lama Tourism Village is
a tourist village with a wide range of tourism potential, and that natural
conditions with beautiful panoramas, strategic locations, and adequate
access from the city are internal factors that contribute to the Tiwingan
Lama tourist village's strength. (2) External factors that become an
opportunity for the development of the Tiwingan Lama tourist village are
changing tourism trends during the pandemic by making the tourist
village a local tourism potential for village tourism, while the village's
weakness is the low quality of village human resources in terms of
tourism. which are still largely unexplored, while the obstacles in the
development of the Tiwingan Lama tourist village are the potential for
flooding and (soil) landslides and the lack of support from the local
government, and (3) based on the results of the A'WOT analysis of the
condition of Tiwingan Lama Village, the strategy used most appropriate
to use in developing tourism ta in the tourist village of Tiwingan Lama is
an S-O strategy, namely by developing the potential of tourism products
in the village of Tiwingan Lama.
AHP; SWOT;

\section{Pendahuluan}

Desa Wisata Tiwingan Lama meraih Juara 4 Nasional untuk Desa Wisata Kategori Berkembang. Dikelilingi oleh Bendungan Riam Kanan dan gugusan pulau kecil serta Kawasan Hutan Lindung Tahura Sultan Adam, tak heran jika pemandangan dari puncak Bukit Matang Kaladan, Desa Tiwingan yang ada di desa ini sangatlah indah. Tak jarang orang lokal menyebutnya sebagai 'Raja Empat Mini'. Tidak hanya itu, Desa Tiwingan Lama, Kecamatan Aranio, juga menjadi tempat fovorit para pemancing dan anak-anak pecinta alam. Desa ini juga sempat menjadi tempat pembibitan Kayu Ulin terbesar se-Indonesia pada tahun 2019, di lokasi inilah digalakkan program adopsi pohon, budidaya madu kelulut, budidaya ayam kampung petelor, serta pupuk asap cair.

Potensi alam yang dimiliki Desa Wisata Tiwingan Lama merupakan salah satu keunggulan bersaing yang dimiliki Desa Tiwingan Lama dibandingkan desa wisata lain yang ada di Kalimantan Selatan. Kegiatan pariwisata yang memanfaatkan keaslian lingkungan alam, dimana terjadi interaksi antara lingkungan alam dan aktivitas rekreasi, konservasi dan pengembangan, serta antara penduduk dan wisatawan ini sering disebut sebagai ekowisata (Hadinoto, 1996).

Kegiatan ekowisata di Desa Tiwingan Lama menjadi desa wisata memberikan dampak positif bagi masyarakat sekitar, yang hingga tahun 2020 tercatat $60 \%$ masyarakat desa bergerak di sektor pariwisata. Selain itu, sektor pariwisata juga telah sukses menurunkan angka pengangguran yang ada di desa tersebut. Beberapa lapangan kerja baru yang tercipta dari sektor pariwisata ini di antaranya adalah tukang ojek, agen perjalanan wisata, tempat penyewaan alat-alat camping, tukang ojek sepeda motor dan perahu, warung makan, serta tempat parkir.

Berdasarkan uraian di atas, dapat dilihat bahwa sektor pariwisata memberikan dampak yang signifikan bagi perekonomian masyarakat Desa Tiwingan Lama. Namun sejak meluasnya pandemi Covid-19, sejak tahun 2020, sektor pariwisata mati suri. Begitu pula dengan pendapatan masyarakat yang turun drastis. Meskipun pemerintah telah menggalakkan trend wisata lokal yang lebih aman dari pandemi, karena dapat ditempuh dengan kendaraan pribadi, kenyataannya sektor pariwisata di Desa Tiwingan Lama masih belum kembali normal. Untuk itulah peneliti tertarik untuk 
menganalisis strategi apa yang tepat untuk digunakan dalam mengembangkan pariwisata di Desa Tiwingan Lama.

Berdasarkan pemasaahan diatas maka dilaksanakan penelitian dengan tujuan untuk mengetahui faktor-faktor internal dan eksternal objek wisata Desa Wisata Tiwingan Lama serta untuk mengetahui strategi pengembangan yang tepat dalam meningkatkan jumlah wisatawan Desa Wisata Tiwingan Lama.

Pariwisata telah menjadi salah satu kekuatan pendorong ekonomi utama di banyak negara maju. Dimana pariwisata pedesaan adalah salah satu yang telah mengalami pertumbuhan yang lebih besar dalam beberapa dekade terakhir (VillanuevaÁlvaro et al., 2017).

Desa wisata merupakan bentuk integrasi antara atraksi, akomodasi, dan fasilitas pendukung yang disajikan dalam suatu struktur kehidupan masyarakat yang menyatu dengan tata cara dan tradisi yang berlaku (Nuryanti, 1993). Concept, Perspective and Challenges, makalah bagian dari laporan konferensi internasional mengenai pariwisata budaya). Desa wisata didefinisikan sebagai sebagian atau keseluruhan wilayah desa yang memiliki potensi, produk, dan aktivitas wisata yang dapat dimanfaatkan untuk pengembangan pariwisata dan dikelola oleh kelompok masyarakat di desa secara berkelanjutan (Beoang \& Suryasih, 2018).

Lebih lanjut, (Morrison, 2013) telah mengidentifikasi bahwa pariwisata berbasis alam merupakan salah satu segmen pasar yang potensial untuk tumbuh, seperti konsep pariwasata yang dimiliki oleh Desa Wisata Tiwingan Lama. Pariwisata berbasis alam memainkan peran penting dalam menghasilkan produk pariwisata kelas dunia. Peran dari wisata alam meliputi (Morrison, 2013) :

1. Membantu memperluas basis produk regional dengan menyediakan layanan tambahan atau pengalaman untuk melengkapi akomodasi dan atraksi utama.

2. Memberikan pengalaman wisata khusus yang menarik bagi ceruk pasar

3. Memberikan peluang investasi berbiaya rendah kepada masyarakat daerah/lokal.

4. Dapat mengurangi dampak sosial dan lingkungan yang merugikan dengan menyediakan sarana pengendalian kegiatan pariwisata.

5. Menyediakan sumber sumber daya pengelolaan kawasan perlindungan melalui biaya perizinan

6. Dapat lebih menyebarkan pesan perlindungan lingkungan.

A'WOT - Hierarchical Decision Making Approach, Analisis SWOT memiliki keterbatasan, seperti fakta bahwa setiap faktor tidak dapat diukur secara kuantitatif tetapi menggabungkannya dengan AHP memungkinkan penyajian strategi yang lebih sesuai dengan tujuan (Kurttila et al., 2000) Analisis A'WOT yang digunakan dalam penelitian ini karena memiliki kelebihana yang dapat secara bersamaan membahas karakteristik kualitatif SWOT dan karakteristik kualitatif AHP. Analisis A'WOT sebagian besar dilakukan dalam tiga tahap: langkah pertama bertujuan untuk mengidentifikasi arah penetapan strategi atau faktor-faktor yang mempengaruhi pengambilan keputusan yang ingin diajukan peneliti melalui penelitiannya. Pada langkah kedua, faktor-faktor yang dipilih dengan analisis SWOT dianalisis menggunakan metode AHP. Analisis kemudian dilanjutkan dengan menyusun hierarki dan menghitung bobot relatif melalui perbandingan berpasangan. Sebagai langkah terakhir, bobot keempat faktor SWOT yang dihasilkan selama fase kedua dikalikan dengan bobot Strengths (S), Weaknesses (W), Opportunities (O), dan Threats (T) untuk akhirnya menghasilkan prioritas akhir.

Menurut (Kurttila et al., 2000) merupakan peneliti pertama yang menyajikan 
analisis pentingnya akhir faktor menurut kelompok menggunakan SWOT dan AHP. Kurttila mengembangkan kerangka ilmiah A'WOT sambil berfokus pada kasus Runni Center di Finlandia dalam sebuah studi tentang sertifikasi hutan. Sejak itu, Pesonen, Kurtila, Kangas, Kajanus, dan Heinonen menamakan analisis SWOT-AHP yang ada sebagai A'WOT, dan mereka telah menerapkan pendekatan penelitian ini ke berbagai bidang (Pesonen et al., 2001). Pada tahun 2004, pakar pariwisata lokal memperluas cakupan analisis ke pariwisata untuk mempromosikan pariwisata pedesaan di wilayah Kassel Jerman dan wilayah Ylasavo Finlandia (Kurttila et al., 2000). Menurut (WICKRAMASINGHE \& Takano, 2009) menggunakan analisis A'WOT untuk secara sistematis menetapkan strategi untuk meningkatkan industri perjalanan. Berbagai studi pariwisata ini menunjukkan bahwa pendekatan analisis A'WOT dapat diterapkan secara aktif untuk menentukan prioritas alternatif kualitatif yang sulit diterjemahkan secara sederhana menjadi angka kuantitatif, dan bahwa pendekatan tersebut pada akhirnya dapat menghasilkan keputusan yang lebih sistematis dan layak.

\section{Metode Penelitian}

Penelitian ini dilakukan pada Desa Tiwingan Lama, Kecamatan Aranio, Kabupaten Banjar. Pencarian data dilakukan langsung ke lokasi Kawasan Desa Wisata Tiwingan Lama, agar data yang diperoleh untuk penelitian ini terbukti kebenarannya. Data yang diperoleh akan digunakan dalam pemecahan masalah dalam proses penelitian.

Pengumpulan data yang digunakan untuk perumusan strategi pengembangan desa wisata Tiwingan Lama adalah dengan menggunakan kajian literature, Focus Group Discussion, dan wawancara mendalam. FGD dilaksanakan bersama pemuka desa yang meliputi Kepala Desa, Ketua Pokdarwis, serta Ketua Kelompok Tani Hutan. Pemilihan narasumber dalam wawancara ditentukan secara purposive sampling berdasarkan keterkaitannya dengan pengelolaan desa wisata Tiwingan Lama. Para narasumber tersebut juga sebagai expert yang berperan dalam melakukan perbandingan berpasangan saat AHP. Jumlah total narasumber untuk perbandingan berpasangan sebanyak 6 orang. Jumlah individu sedikit dikarenakan untuk menjaga kekonsistenan pada perbandingan berpasangan AHP (Yavuz \& Baycan, 2013).

Penggunaan analisis A'WOT secara garis besar terbagi menjadi tiga tahapan. Tahap pertama adalah mengidentifikasi faktor SWOT meliputi faktor internal (strengths dan weaknesses) dan eksternal (opportunities dan threats). Tahap kedua adalah menerapkan teknik AHP untuk memperoleh bobot dari tiap grup SWOT. Tahap ketiga menggunakan teknik AHP untuk membandingkan tiap faktor dalam grup SWOT. Pada penelitian ini penentuan strategi dilakukan dengan matriks strategi SWOT untuk kemudian dibandingkan berpasangan dengan faktor SWOT untuk mengetahui prioritas dan tingkat kepentingannya.

\section{Hasil dan Pembahasan}

1. Profil Desa Wisata Tiwingan Lama

Tiwingan Lama merupakan salah satu desa di Kecamatan Aranio, Kabupaten Banjar, Provinsi Kalimantan Selatan, Indonesia. Dengan total luas wilayah sebesar 29,41 km2, desa tiwingan lama terdiri atas hamparan perbukitan yang berada di wilayah Waduk Riam Kanan. Desa Tiwingan Lama berjarak 54,2 $\mathrm{km}$ dari kota Banjarmasin dengan waktu tempuh perjalanan sekitar $1,5 \mathrm{~km}$. Akses dan kondisi jalan menuju desa ini sudah terbangun dengan baik

2. Potensi Wisata Desa Tiwingan Lama

Potensi wisata yang dimiliki Desa Tiwingan Lama sangat besar dan amat prospektif untuk dikembangkan. Lokasi 
wisata utamanya adalah Bukit Matang Kaladan. Dari puncak Matang Kaladan, wisatawan disuguhi pemandangan indah berupa pulau-pulau kecil di Waduk Riam Kanan yang mirip dengan kawasan Raja Ampat di Papua. Selain itu, tampak pula Pembangkit Listrik Tenaga Air (PLTA) Riam Kanan, Juwor, Bukit Alimpung, Bukit Atawang, dan Pulau Rusa. Di Matang Kaladan saat ini terdapat berbagai fasilitas seperti empat gazebo, 18 spot foto, warung kuliner, dan penginapan.

Puncak Matang Keladan merupakan salah satu lokasi favorit wisatawan karena memiliki panorama yang sangat indah, serta tersedia banyak spot foto. Sedangkan Bukit Alimpung, selain memiliki panorama yang indah juga merupakan tempat pembibitan kayu ulin terbesar di Indonesia, peternakan madu kelulut, ayam kampong petelor, serta produksi asap cair. Bukit ini menjadi tempat favorit untuk wisata edukasi (Riyanto \& Kurniawati, 2018). Lain halnya dengan Bukit Atawang, lokasi ini merupakan lokasi favorit bagi para pecinta alam, karena memiliki bukit yang dapat digunakan sebagai arena panjat tebing. Selain itu di desa Tiwingan Lama juga terdapat beberapa jala apung serta Juwor yang menjadi tujuan utama para penggemar hobi memancing. Dan yang tak kalah penting adalah wisata susur pulau, dimana para wisatawan dapat berkeliling menyusuri pulau-pulau yang ada disekitaran waduk Riam Kanan, pulaupulau tersebut ada menawarkan keindahan alam yang alami, air terjun serta satwasatwa liar khas Kalimantan Selatan.

3. Identifikasi Faktor SWOT Desa Tiwingan Lama

Berdasarkan kajian literatur dan FGD diperoleh faktor-faktor SWOT. Faktor-faktor ini kemudian dirangkum dari banyaknya faktor yang teridentifikasi (Tabel 1). Hal ini dikarenakan ada kemiripan antar faktor dan masih terkait. Selain itu penyederhanaan dilakukan untuk mengurangi jumlah perbandingan berpasangan yang dapat muncul nantinya (Pesonen et al., 2001)

\section{Tabel 1. Faktor-faktor SWOT}

Desa Tiwingan Lama

\begin{tabular}{llll}
\hline S1 & lokasi mudah dicapai & O1 & banyak potensi belum dikembangkan \\
\hline S2 & areal yang luas & O2 & jumlah wisatawan milenial meningkat \\
\hline S3 & banyak spot instagram & O3 & berubahnya trend wisata \\
\hline S4 & wilayah strategis (memiliki pelabuhan) & \\
\hline \multicolumn{1}{c}{ WEAKNESS } & THREAT \\
\hline W1 & rendahnya pengetahuan masyarakat & T1 & Pandemic \\
\hline W2 & kurangnya kerjasama masyarakat & T2 & pesaing dalam industri pariwisata \\
\hline W3 & rendahnya kesadaran akan kebersihan & T3 & kurangnya support pemerintah daerah \\
\hline W4 & infrastruktur pariwasata kurang memadai & T4 & potensi banjir dan tanah longsor \\
\hline W5 & souvenir/oleh-oleh sangat sedikit & & \\
\hline
\end{tabular}

Sumber : data diolah, 2021

4. Penyusunan Hierarki Keputusan dan Strategi

Penyusunan strategi menggunakan matriks TOWS yang disusun bersama dari kajian literatur dan FGD. Strategi disusun dengan memperhatikan faktorfaktor dari masing-masing grup SWOT dan ketentuan matrik SWOT. Hasilnya diperoleh 4 strategi (Tabel 2).

Tabel 2. Strategi Desa Wisata Tiwingan Lama Menggunakan Matriks SWOT

\begin{tabular}{ccc}
\hline Matriks & Strength & Weakness \\
SWOT & \\
\hline
\end{tabular}




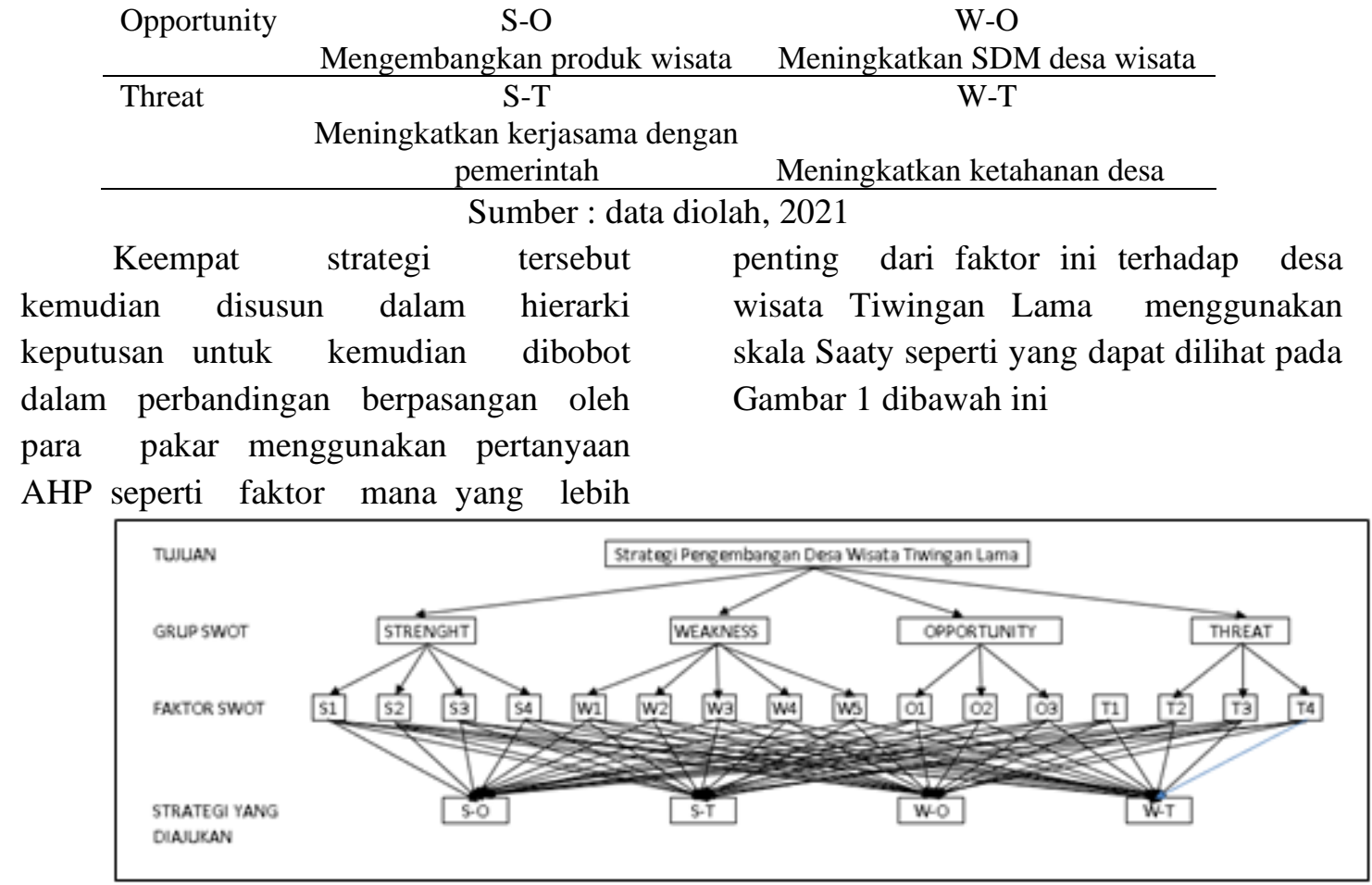

Sumber : data diolah, 2021

Gambar 1. Hierarkhi dalam A'WOT

Hasil perbandingan berpasangan menunjukkan bahwa strategi SO dengan nilai tertinngi sebesar 0,417 menjadi prioritas utama (Gambar 2). Inkonsistensi dari perbandingan berpasangan sebesar 0,04 , sehingga hasil dapat dikatakan konsisten karena kurang dari 0,1 .

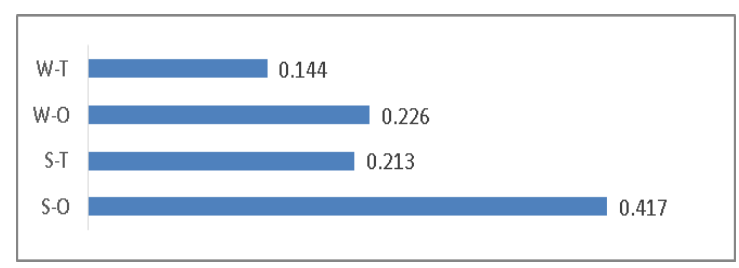

Sumber: data diolah, 2021

Gambar 2.

Hasil perbandingan berpasangan strategi

5. Implikasi Penelitian

Strategi S-O adalah strategi mengembangkan produk wisata. Strategi ini menjadi strategi prioritas utama karena dianggap sebagai strategi yang paling efektif untuk meningkatkan daya tarik wisatawan dalam mengunjungi desa wisata Tiwingan Lama. Pengembangan produk wisata yang dikembangkan ini meliputi :

a. Daya tarik destinasi yang didukung oleh infrastruktur penunjang yang memadai. Meskipun panorama alam di Desa Tiwingan Lama sudah indah, namun untuk menjadi desa wisata, desa Tiwingan Lama masih perlu berbenah diri, mempercantik dan membersihkan lingkungan desa serta obyek wisata dapat miningkatkan daya tarik terhadap wisatwan

b. Menambah paket-paket wisata di pulau-pulau yang ada di desa Tiwingan Lama beserta atraksi-atraksi yang ada didalamnya, hal ini dapat menjadi pengalaman yang menarik bagi para wisatawan sekaligus sarana masyarakat untuk memperkenalkan budaya asli daerah. 
c. Menambah produk-produk wisata yang belum ada sebelumnya seperti taman edukasi dan sarana outbond

d. Meningkatkan variasi dan sarana promosi produk-produk kuliner sehingga wisatawan dapat merasakan kuliner khas daerah serta membawanya pulang sebagai oleh-oleh.

e. Mengembangkan konsep desa wisata sesuangguhnya kepada para wisatawan, dimana para wisatawan dapat menginap didesa ikut merasakan aktivitas masyarakat asli desa seperti penambak jala apung, petani hutan dll.

f. Menambah jumlah spot-spot yang menarik dan instagrammable untuk meningkatkan daya tarik destinasi wisata melalui Instagram

\section{Kesimpulan}

Berdasarkan pembahasan pada bab-bab sebelumnya, dapat ditarik kesimpulan bahwasanya Desa Wisata Tiwingan Lama merupakan desa wisata yang memiliki potensi wisata yang sangat beragam, faktor internal yang menjadi kekuatan desa wisata Tiwingan Lama adalah kondisi alam dengan panorama yang indah, letak yang strategis, serta akses yang memadai dari kota menuju desa wisata, sedangkan kelemahan Desa Tiwingan Lama adalah rendahnya kualitas SDM desa dari segi pariwisata.

Faktor eksternal yang menjadi peluang bagi berkembangnya desa wisata Tiwingan Lama adalah berubahnya trend pariwisata selama pandemi dengan menjadikan desa wisata sebagai wisata lokal yang potensi wisata desanya yang masih banyak belum digali, sedangkan hambatan dalam pengembangan desa wisata Tiwingan Lama adalah adanya potensi banjir dan longsor serta kurangnya dukungan dari pemerintah daerah setempat.

Berdasarkan hasil analisis A'WOT terhadap kondisi Desa Tiwingan Lama, strategi yang paling tepat digunakan dalam mengembangkan pariwisata di desa wisata Tiwingan Lama adalah strategi S-O, yaitu dengan mengembangkan potensi produk wisata yang ada di Desa Tiwingan Lama.

\section{BIBLIOGRAFI}

Beoang, D. D., \& Suryasih, I. A. (2018). Identifikasi Potensi Desa Wisata Sangeh, Kabupaten Badung.Google Scholar

Hadinoto, K. (1996). Perencanaan pengembangan destinasi pariwasita. Penerbit Universitas Indonesia. Google Scholar

Kurttila, M., Pesonen, M., Kangas, J., \& Kajanus, M. (2000). Utilizing the analytic hierarchy process (AHP) in SWOT analysis - a hybrid method and its application to a forest-certification case. Forest Policy and Economics, 1(1), 41-52. Google Scholar

Morrison, A. M. (2013). Marketing and managing tourism destinations. Routledge. Google Scholar

Nuryanti, W. (1993). Concept, Perspective and Challenges, makalah bagian dari Laporan Konferensi Internasional mengenai Pariwisata Budaya. Yogyakarta: Gadjah Mada University Press. Hal, 2-3. Google Scholar

Pesonen, M., Kurttila, M., Kangas, J., Kajanus, M., \& Heinonen, P. (2001). Assessing the priorities using A'WOT among resource management strategies at the Finnish Forest and Park Service. Forest Science, 47(4), 534-541. Google Scholar

Riyanto, S., \& Kurniawati, I. D. (2018). Rancang Bangun Website Desa KresekMadiun Untuk Media Informasi Potensi Wisata Alam Dan Kulinier. Jurnal Sistem Informasi Dan Ilmu Komputer Prima (JUSIKOM PRIMA), 1(2). Google Scholar

Villanueva-Álvaro, J.-J., Mondéjar-Jiménez, 
J., \& Sáez-Martínez, F.-J. (2017). Rural tourism: Development, management and sustainability in rural establishments. Sustainability, 9(5), 818. Google Scholar

Wickramasinghe, V. S. K., \& Takano, S. (2009). Application of combined SWOT and analytic hierarchy process (AHP) for tourism revival strategic marketing planning. Proceedings of the Eastern Asia Society for Transportation Studies Vol. 7 (The 8th International
Conference of Eastern Asia Society for Transportation Studies, 2009), 189. Google Scholar

Yavuz, F., \& Baycan, T. (2013). Use of swot and analytic hierarchy process integration as a participatory decision making tool in watershed management. Procedia Technology, 8, 134-143. Google Scholar

\section{Copyright holder :}

Sari Hepy Maharani, Tarman Effendi (2022).

First publication right :

Action Research Literate

This article is licensed under:

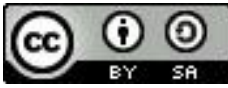

